\section{1.まえが ぎ}

本連載の目的は，若者があまり海外に出ないという現状を踏ま え，もっと世界に出ていくことを勧めることかと思います。帛の手 段の一つとしてストックホルム滞在記の執筆機会を頂いているので すが，今回は留学を取り巻く現状について，私が好きなゲーム理論 を用いて議論させて頂きたいと思います。ゲーム理論を御存じでな い方も容易に読めるよう，ゲーム理論特有の用語をできる限り用い なかったため，若干議論をはしょったところがありますが，御了承 下さい.

\section{2. 問題設定}

「若手研究者（以下，若手）はもっと海外に行くべきだ，と言っ ているのに行かない」と扔っしゃっているシニア研究者や教授の 方々（以下，シニア）がいらっしゃる現状を打開するにはどうす ればよいのか，という問題を議論してみようと思います。

まず，この問題に現れた主体を列挙すると，若手とシニアの二 者です，若手の取り得る選択肢としては，海外に“行く”，“行か ない”などがあり, シニアの取り得る選択肢としては, 海外に“行 くべきだと言う”，“行くべきだと言わない”などがあると思いま す.シニアが,「若手は海外に行くべきだ」と扔っしゃったりす るのは, シニアと若手の相互作用の結果として, 若手が海外に行 くことを望んでいるからでしょう。この相互作用一もう少し正確 に言うと, 複数の意思決定主体間の相互作用一を議論する数学理 論としてゲーム理論があります.

ゲーム理論に扔いて最も単純な戦略形 2 人ゲームという問題 設定は, 次式のように二つの最適化問題の組合せにより表現され ます。

$$
\left\{\begin{array}{l}
\max _{x_{1} \in X_{1}} f_{1}\left(x_{1}, x_{2}\right) \\
\max _{x_{2} \in \mathscr{X}_{2}} f_{2}\left(x_{1}, x_{2}\right)
\end{array}\right.
$$

添字の 1 及び 2 は意思決定主体 (ゲーム理論の用語ではプレイ ヤ) のインデックス, 集合 $\mathscr{X}_{1}$ は主体 1 が取り得る選択肢全ての 集合, $x_{1}$ は主体 1 の取る選択肢 (ゲーム理論の用語では戦略), $f_{1}$ は主体 1 が最大化したい目的関数（ゲーム理論の用語では効用関 数）をそれぞれ表します。

これを先ほどの問題設定に当てはめましょう。ここでは, 主体 1 を若手, 主体 2 をシニアとします。この場合, 先ほど述べた, 海外に“行く”, “行かない”という若手の取り得る選択肢を集合 帛の要素, 海外に“行くべきだと言う”, “行くべきだと言わない” というシニアの取り得る選択肢を集合 $\mathscr{X}_{2}$ の要素と設定します。

こうなると残る目的関数 $f_{1}, f_{2}$ を決めたくなるのですが，そう する代わりに現状がどうなっているかを考えましょう。 シニアが “行くべきだと言っている”のに若手が“行かない”と言うこと
を現状とし，表で表すと次のようになります。

\begin{tabular}{|l|l|l|}
\hline & 行くべきだと言う & 行くべきだと言わない \\
\hline 行 く & & \\
\hline 行かない & 現 状 & \\
\hline
\end{tabular}

第 1 列が若手の選択肢, 第 1 行がシニアの選択肢を表していま す。ゲーム理論では, 現状とは, 相手の選択が今と同じ限り, 各 主体は選択できる選択肢のうち自分にとって最も良い選択をして いる状態と捉えます，先の表で言えば「若手が“行かない”とい う選択をしているときには，シニアにとっては“行くべきだと言 う”方が“行くべきだと言わない”よりは良い」と考元, 同時に「シ ニアが“行くべきだと言っている”ときには, 若手にとっては“行 かない”方が“行く”より良い」と考えます。１番目は条件を外 して「シニアにとっては“行くべきだと言う”方が“行くべきだ と言わない”よりは良い」でもよいかもしれませんが，現状を把 握する上ではこのような細かいことはそれほど重要ではありませ 几. また, 目的関数 $f_{1}, f_{2}$ はこの条件に合っているものであれば良 く, 具体的に考える必要はありませんので,ここでは議論しません。

\section{3. 問題解決に向けて}

若手が海外に“行かない”という現状を打開したい場合にで きることは何かという問題を, ゲーム理論の枓組みの中でシス テマティックに考えてみましょう，先の式の枠組みを前提とし て考元ると，我々にできることは，(1) 選択肢（集合 $\mathscr{X}_{1}, \mathscr{X}_{2}$ の 要素) を変更すること, (2) 関数 $\left(f_{1}, f_{2}\right)$ の形を変えること, (3) 主体を変更することの三つに限られます。

シニアの中には“行きやすい環境を整える”ということをなさっ ている方もいらっしゃるように思います。ここれは (1) 選択肢を増 やすことに相当します。まずこれを考えてみましょう，そういえ ば“海外に行きやすい制度を作ったのに若手が利用しない”など というような苦言を呈されている人を抄かけしたような記憶が ありますので，これが現状と捉えてみましょう．表は次のように 変わりました。

\begin{tabular}{|l|l|l|}
\hline & 行くべきだと言う行くべきだと言わ \\
ない & \begin{tabular}{l} 
行きやすい整える \\
\hline
\end{tabular} \\
\hline 行 & & \\
\hline 行かない境を \\
\hline
\end{tabular}

これをゲーム理論的に捉えますと, 若手が“行かない”場合で も“行きやすい環境を整える”方が“行くべきだと言う”だけや“言 わない”よりはまだ良い，となります。もち万ん，若手のことが よく分からないので，きっと若手が “行く”ようになるという期 待を达めて“行く環境を整えた”と考える方法もありますが，こ こでは簡単のため, 先ほど説明した簡単なゲーム理論の枠組みだ 
けで考えてみましょう。“行きやすい環境を整える”ことは面倒 なことであり, かつ現状若手が“行かない”にもかかわらずシニ アがこの戦略をとるのは一見合理的ではありません，ただ，ゲー ム理論的にはそこに合理的な理由があると考えます。ゲーム理論 的に説明を付けるために考えれば，決して私の意見ではありませ んが，例えば「我々は何も対策を取っていないわけではない」と 主張できるというメリットが環境を整えるための面倒さを上回る ので“行きやすい環境を整える”ということかもしれません．も しそうだとすると，手段それ自体が目的と化していると捉えられ ても仕方ないでしょう。

また, “行きやすい環境を整える”ことは, 若手が“行く”方が“行 かない”より良いと考えるようになるほど, 目的関数 $f_{1}$ の形を変 えられなかったということです，要するに，効果がない選択肢を 多大な労力をかけて行った，ということです．重ねて言いますが, これは決して私の意見ではありません。あくまで，ゲーム理論を 当てはめて議論するとそうなるというだけのことです.

今度はシニアの選択肢を変えてみて，“無理やり行かせる”の みとすれば, 次のようになります。

\begin{tabular}{|l|l|}
\hline & 無理やり行かせる \\
\hline 行 く & 現 状 \\
\hline 行かない & \\
\hline
\end{tabular}

もし目的が，若手の選択肢を“行く”に変えることであるなら ば，それ以外の選択肢をなくしてしまえばよいと思います。ヨー ロッパの多くの国では, 例えば 3 か月の国外研究経験が博士課程 の中に含まれていますが，それは若手を国外に行かせるためのう まい仕組みだと思われます。

しかしながら，現状は「“行く環境を整えた”のに“行かない”」 ということであれば，“無理やり行かせる”という選択肢を含めて 考えても次のような表になっていると捉えるべきだと思われます.

\begin{tabular}{|c|c|c|c|}
\hline & \begin{tabular}{l|l} 
行くべきだと行くべきだと \\
言う \\
言わない
\end{tabular} & \begin{tabular}{|l|} 
行きやすい \\
環境を整える
\end{tabular} & \begin{tabular}{|l} 
無理やり行か \\
せる
\end{tabular} \\
\hline 行 < & & & \\
\hline 行かない & & 現 状 & \\
\hline
\end{tabular}

この現状をゲーム理論的に捉えると，“無理やり行かせる”と何 かあったときに責任を負えないため，“行きやすい環境を整える” だけにしておこう，というふうにシニアが選択しているというこ とでしょうか. 結局のところ, 若手が「行かない」のに，単に“行 きやすい環境を整える”〈らいしかしていないシニアは, 現状打 破に有効な措置を取る気はないということを意味しています，本 当に若手が海外に“行く”ようにするには，“無理やり行かせる” しかないような仕組みを作ってしまえばよいと思われます。

次に (2) 関数の形について考えてみましょう。例えば，一度海 外に行くと，また行きたくなることがあるように思います．事実， これまで既に海外滞在経験のある若手研究者が, 最近整えられた 制度を使って再度行っている例が身の回りにもあります。私も正 直なところ, 留学前はデメリットを大きく上回るメリットがある と感じておりませんでした。しかし，今は大きなメリットを感じ ています。例えば，研究は競争という側面がありますから，相手 のことを知っていれば競争上有利だと思います。留学前は海外の ことを知っているつもりになっていました，今は，知らないこと がまだまだたくさんあるだろうから，また行けば競争上より有利 になると感じています。ただ，算数を知らない子供に，算数を自
由意思で学ぶように動機付けるのが難しいことと同様, 留学を知 らずメリットを感じていない若手に留学を自由意思で選択するよ うにさせるのは難しいと思います。恐らく，留学に意義がないと 思っている若手は多くないと思いますが，デメリットをはるかに 上回るメリットがあると感じさせるのは難しいと思います。その 意味でも，“無理やり行かせる”仕組みを作ることは有効と思い ます。

また，他の国からはどんどん留学しているのに日本からは少な いとか, 昔は留学が難しかったけれども頑張って留学したとおっ しゃる方もいますが，それはその国・その時代では関数の形が現 在の日本と違っていただけのことでしょう。本当に若手が海外に 自発的に行きたい世の中にするためには，例えば日本にもそのよ うな国と同様の政治体制を樹立させたりすると良いでしょう。も しかすると，独裁的なシニアの元からは，若手がどんどん海外に 行くかもしれませんね. 日本の研究環境が劣悪になりつつあると いわれていますが，これも若手が世界に行くという観点から言え ば，非常に有効な施策にほかなりません。皆様も，もし日本がそ のような社会なら，もっと海外に行く気が強くなるでしょう.もっ とも，副作用が心配です。

最後に，これまでの表の形では表現できなくなりますが，（3） 主体を加えるということについて考えてみたいと思います。例え ば配偶者が海外好き，あるいは日本嫌い，となると，若手として は海外に“行く”方のメリットが高まると思います。こういう方 も周りに複数いらっしゃるように思います。

\section{4. むす び}

以上のような問題設定にはたくさん反論はあるかと思います. 例えば，本来若手は海外に行く方が行かないよりまだ良いのに， 本当のことが分かっていないから海外に行かないのだ，という反 論があるかもしれません，そのとおりですが, 本当のことが分かっ ていないのであれば，自由意思で行かせるようにすることは難し いわけで，そこで海外に“行きやすい環境を整える”ということ をしても，それだけでは意味がないということになりかねません.

また，若手が海外に行かないのは若手だけの問題で，シニアの 選択など関係ないはずだ，という反論もあるかもしれません，確 かに，以上のような議論が発生したのは，若手だけでなく，シニ アを相互作用のある主体として考えたためです。しかし，若手が 海外に行かないのをシニアが問題視しているということ自体が若 手とシニアの相互作用によるものですから，ここではこのような 設定としました。

一方で，留学を取り巻く問題の中には海外に“行きたいけれど も行けない”という問題もあるかと思いますが, 本連載の目的と 外れていきますので，本稿では除外させて頂きました，ただ，本 稿での議論と同様に, 若手の取り得る選択肢として, 海外に“行 けない”, “行く”などとし, シニアの取り得る選択肢として, 海 外に“行きにくいような環境を整える”, “行きやすい環境を整える” などと設定して議論することは可能だと思います。気になる方は 是非御自身で問題を設定して考えてみて頂ければと思います.

このように, ゲーム理論は議論を展開する上で大変有益なツー ルです，特に，文化的にシニアに都合の悪いことを議論しにくい 日本においては, 若手にとって大変便利なツールだと思います. ゲーム理論の教科書は難解な数学ばかりで放り投げたくなります が, ゲーム理論を勉強するメリットを感じて頂ければ幸いです. 